\title{
PENGARUH HARGA DAN KUALITAS PRODUK TERHADAP MINAT BELI SAYURAN ORGANIK DI PASAR SAMBAS MEDAN
}

\author{
Ruri Putri Utami ${ }^{1)}$, Hendra Saputra $\left.{ }^{2}\right)^{*}$ \\ ${ }^{1)}$ Alumni Fakultas Ekonomi, Universitas Negeri Medan \\ 2) Fakultas Ekonomi, Universitas Negeri Medan \\ ${ }^{*}$ Penulis Korespondensi: hensap75@gmail.com
}

\begin{abstract}
Penelitian ini bertujuan untuk mengetahui pengaruh harga dan kualitas produk terhadap minat beli sayuran organik di Pasar Sambas Medan. Penelitian ini dilaksanakan di Pasar Sambas Medan, dengan populasinya adalah pembeli sayuran organik. Teknik pengambilan sampel menggunakan purposive sampling dengan jumlah sampel sebanyak 100 responden. Teknik pengumpulan data dalam penelitian ini dilakukan dengan cara menyebarkan angket (kuesioner) yang diolah secara statistik dengan bantuan SPSS 20.0 dan menggunakan Analisis Regresi Berganda. Dari Hasil Uji Regresi linear berganda diperoleh Y $=1,554+$ $0,305 \mathrm{X} 1+0,876 \mathrm{X} 2$. Artinya jika harga dan kualitas produk konstan maka minat beli akan konstan. Jika perubahan harga meningkat sebesar satu satuan, tingkat minat beli akan meningkat sebesar 0,305 satuan. Jika kualitas harga meningkat sebesar satu satuan maka minat beli akan meningkatkan sebesar 0,876 satuan. Untuk mengetahui pengaruh variabel bebas terhadap variabel terikta secara simultan digunakan koefisien determinasi dengan hasil $94,1 \%$. Hasil ini menunjukkan bahwa pengaruh antara harga dan kualitas produk terhadap minat beli secara simultan pada Pasar Sambas sebesar 94,1\% sedangkan sisanya 5,9\% dijelaskan oleh variabel-variabel lain diluar model penelitian ini. Berdasarkan Uji F, Uji Hipotesis secara simultan, variabel harga dan kualitas produk secara bersama-sama berpengaruh signifikan terhadap minat beli. Setelah dilakukan Uji T, Uji hipotesis secara parsial variabel harga dan kualitas secara parsial berpengaruh signifikan terhadap minat beli. Kesimpulan yang bisa ditarik dari hasil analisis pada Pasar Sambas Medan adalah bahwa harga dan kualitas produk berpengaruh terhadap minat beli sayuran organic.
\end{abstract}

Keyword: Harga, Kualitas Produk, dan Minat Beli 


\section{PENDAHULUAN}

Gaya hidup sehat sudah menjadi trend di masyarakat dunia termasuk juga Indonesia. Tidak hanya menjaga kesehatan dengan berolah raga tetapi juga mengkonsumsi makanan-makanan sehat berupa buah dan sayuran. Mengkonsumsi buah-buahan dan sayursayuran adalah cara yang baik dalam mewujudkan gaya hidup sehat. Namun ada hal lain yang harus diketahui bahwa buah dan sayuran yang dikonsumsi tidak lepas dari pengaruh zat-zat kimia seperti pestisida dan pupuk kimia/sintesis, sebagai bahan yang digunakan untuk meningkatkan jumlah produksi pertanian. Jumlah konsumsi produk pertanian yang besar berbanding lurus dengan besarnya jumlah zat kimia yang digunakan. Hal tersebut membuat timbul masalah baru seperti menurunnya kualitas tanah dan mencemari air tanah serta berefek buruk juga bagi pengkonsumsi buah dan sayuran tersebut. Semakin banyak zatzat kimia yang terkandung maka buah dan sayuran tersebut semakin jauh dari kata sehat. Dengan kenyataan tersebut masyarakat mulai beralih memilih sayuran organik yang bebas dari zat yang berbahaya bagi tubuh.

Menurut Swastha dan Irawan (2001 : 339) "Minat beli berhubungan dengan perasaan dan emosi, bila seseorang merasa senang dan puas dalam membeli barang atau jasa maka hal itu akan memperkuat minat beli, ketidakpuasan biasanya menghilangkan minat. Minat beli yang ada dalam diri konsumen merupakan fenomena yang sangat penting dalam kegiatan pemasaran, minat beli merupakan suatu perilaku konsumen yang melandaskan suatu keputusan pembelian yang hendak dilakukan".

Dari pendapat diatas dapat dikatakan bahwa minat beli tersebut timbul dari dalam diri seorang konsumen setelah konsumen tersebut mengkonsumsi dan merasakan sendiri manfaat yang diterima ketika mengkonsumsi suatu produk. Selain itu ada faktor-faktor lain yang mempengaruhi minat beli seorang konsumen. Minat beli konsumen dapat dipengaruhi oleh kualitas produk, harga, lokasi dan kualitas pelayanan.

Menurut (Kotler \& Amstrong, 2001:346) "Produk adalah segala sesuatu yang dapat ditawarkan kepasar untuk mendapatkan perhatian, dibeli, digunakan, atau dikonsumsi yang dapat memuaskan keinginan atau kebutuhan". Selain kualitas produk, harga juga menjadi salah faktor yang mempengaruhi minat beli konsumen karena suatu harga dapat menjadi patokan kualitas suatu produk, dengan harga yang mahal biasanya konsumen berfikir pasti produk yang diberikan memiliki kualitas yang baik dan apabila harga yang ditawarkan murah konsumen masih meragukan kualitas produknya. Suatu harga dapat menjadi patokan kualitas suatu produk, dengan harga yang mahal biasanya konsumen berfikir pasti produk yang diberikan memiliki kualitas yang baik dan apabila harga yang ditawarkan murah konsumen masih rmeragukan kualitas produknya, harga yang rendah atau harga yang terjangkau menjadi pemicu untuk meningkatkan kinerja pemasaran (Ferdinand dalam Faradiba 2013:1-2). 
Menurut Swastha (2002:147) "Harga adalah sejumlah uang (ditambah beberapa kalau mungkin) yang dibutuhkan untuk mendapatkan sejumlah kombinasi dari barang beserta pelayanannya". Selanjutnya, Menurut Annafik (2012) dalam penelitiannya menyatakan bahwa Harga merupakan salah satu penentu pemilihan produk yang nantinya akan berpengaruh terhadap minat pembelian. Harga seringkali dikaitkan dengan kualitas, konsumen cenderung untuk menggunakan harga sebagai indikator kualitas atau kepuasan potensial dari suatu produk.

Menurut Kotler (2009:106) "Kualitas adalah totalitas fitur dan karakteristik yang memampukan produk memuaskan kebutuhan yang dinyatakan maupun tidak dinyatakan". Kualitas suatu produk dapat dinilai berdasarkan sekumpulan kriteria yang berbeda karena mengingat kepentingan dan keterlibatan konsumen berbeda-beda. Persepsi terhadap kualitas mencerminkan perasaan konsumen secara menyeluruh mengenai suatu produk.

Ketika seseorang berbelanja, hal awal yang sering diperhatikan calon konsumen adalah harga, kemudian produk yang akan dibeli, baik tampilan maupun kualitasnya. Harga dan kualitas produk adalah hal penting bagi konsumen. Penetapan harga pada suatu produk haruslah sesuai dan wajar dengan kualitas produk yang ditawarkan. Tingginya harga yang ditawarkan tersebut harus sesuai dengan manfaat yang akan diterima oleh konsumen yang mengkonsumsinya.
Harga yang terlalu tinggi dan terlalu rendah akan mempengaruhi minat beli konsumen. Harga yang terlalu tinggi akan membuat konsumen beralih ke produk lain yang sejenis tetapi dengan harga yang lebih murah, begitu sebaliknya, jika harga yang ditawarkan terlalu rendah konsumen akan ragu dengan kualitas produk yang ditawarkan tersebut sehingga mengurangi minat beli akan produk tersebut. Selanjutnya, tingginya kualitas produk yang ditawarkan akan menarik minat beli konsumen, begitu juga sebaliknya.

$$
\text { Pasar Sambas Medan adalah }
$$

pasar tradisional yang menjual kebutuhan sehari-hari, seperti pakaian,alat kosmetik serta produk pertanian. Produk pertanian yang ditawarkan dipasar ini berupa sayur dan buah, impor maupun lokal, organik maupun sayuran anorganik. Berdasarkan hasil observasi awal yang penulis lakukan, dapat diketahui berbagai keadaan yang terjadi bahwa beralihnya minat beli ini dikarenakan kesadaran masyarakat akan kesehatan semakin tinggi serta berbagai kelebihan yang ditawarkan oleh sayuran organik, seperti kualitas,daya tahan, serta manfaat yang diberikan dibandingkan dengan sayuran biasa atau anorganik, selain itu persepsi masyarakat terhadap sayuran organik bahwa sayuran organik jauh lebih sehat dibandingkan jenis sayuran biasa atau anorganik yang menimbulkan minat beli diantara konsumen. Selanjutnya, dari observasi tersebut terdapat hal yang paling menonjol yaitu harga yang dimiliki oleh sayuran organik jauh lebih tinggi dibandingkan jenis sayuran biasa. 
p-ISSN : 2301-7775

e-ISSN : 2579-8014

JURNAL NIAGAWAN Vol 6 No 2 Oktober 2017

\section{KAJIAN PUSTAKA Harga}

Harga umumnya menjadi hal utama yang diperhatikan oleh calon konsumen ketika ingin membeli produk. Tinggi atau rendahnya harga akan menentukan seseorang dalam membeli satu barang. Melalui harga, seorang bisa memutuskan apakah produk tersebut akan dimiliki dan dikonsumsinya atau sebaliknya. "Harga adalah sejumlah uang yang ditukarkan untuk produk atau jasa, lebih jauh lagi harga adalah jumlah dari seluruh nilai yang konsumen tukarkan untuk jumlah manfaat dengan memiliki atau menggunakan suatu barang dan jasa" (Kotler \& Amstrong 2001:14). "Harga adalah jumlah uang yang telah disepakati oleh calon pembeli dan penjual untuk ditukar dengan barang atau jasa dalam transaksi bisnis normal".(Tandjung, 2004:78). Menurut Saladin (2003:95) pengertian harga adalah "Sejumlah uang sebagai alat tukar untuk memperoleh produk atau jasa. Harga dapat juga dikatakan penentuan nilai suatu produk dibenak konsumen".

Dari hal tersebut di atas, maka dapat disimpulkan bahwa harga adalah jumlah uang atau nilai tukar sebuah barang maupun jasa yang ditetapkan sesuai dengan tingkat kemampuan barang dan jasa tersebut memberikan manfaat kepada pembelinya. Semakin tinggi manfaat yang dirasakan maka harga barang tersebut semakin tinggi pula.

\section{Kualitas Produk}

Kualitas produk merupakan salah satu hal pendukung yang membuat suatu produk dipilih oleh masyarakat untuk dibeli dan dikonsumsi. Kualitas produk yang ditawarkan akan menentukan bagaimana minat masyarakat terhadap produk tersebut. Menurut Kotler (2005:49) "Kualitas produk adalah keseluruhan ciri serta dari suatu produk atau pelayanan pada kemampuan untuk memuaskan kebutuhan yang dinyatakan/ tersirat". Selanjutnya menurut Sedangkan menurut Tjiptono (2004:4) "Kualitas adalah suatu kondisi dinamis yang berhubungan dengan produk dan jasa manusia, proses dan lingkungan yang memenuhi atau melebihi harapan".

Dari penjelasan diatas dapat disimpulkan bahwa kualitas produk adalah keadaan, ciri serta kemampuan sebuah produk dalam menjalankan fungsinya dalam memenuhi serta memuaskan konsumen baik itu dari tampilan, daya tahan, maupun manfaat yang produk tersebut berikan.

\section{Minat Beli}

Minat beli merupakan hasil evaluasi dari dalam diri individu seorang konsumen tentang suatu produk atau jasa,mengenai kualitas,kemampuan serta keuntungan apa saja yang akan diperoleh jika mengkonsumsi produk tersebut. Minat beli ini muncul ketika seorang konsumen melihat suatu produk dan jasa yang ditawarkan, baik dari penampilan, kemasan, serta keunggulan 
produk tersebut. Menurut Simamora (2002:106), "Minat beli terhadap suatu produk timbul karena adanya dasar kepercayaan terhadap produk yang di ingini dengan kemampuan untuk membeli produk." Menurut Kotler (2005:205) "Minat beli konsumen adalah sesuatu yang timbul setelah menerima rangsangan dari produk yang dilihatnya, dari sana timbul ketertarikan untuk mencoba produk tersebut hingga pada akhirnya timbul keinginan untuk membeli sehingga dapat memilikinya".

Dari uraian di atas maka dapat disimpulkan bahwa minat adalah keinginan yang timbul dari hasil pemikiran dan evaluasi mengenai manfaat dan keuntungan suatu produk atau jasa apabila produk dan jasa tersebut dikonsumsi.

\section{METODE PENELITAN}

Lokasi penelitian dilaksanakan di pasar Sambas jalan Sambas No. 1 Medan. Populasinya adalah pembeli sayuran organik. Teknik pengambilan sampel menggunakan purposive sampling dengan jumlah sampel sebanyak 100 responden. Teknik pengumpulan data dalam penelitian ini dilakukan dengan cara menyebarkan angket (kuesioner) yang diolah secara statistik dengan bantuan SPSS 20.0 dan menggunakan Analisis Regresi Berganda.

\section{HASIL DAN PEMBAHASAN \\ Hasil Penelitian \\ Analisis Regrasi Berganda}

Persamaan regresi berganda secara umum adalah :

$$
\mathbf{Y}=\mathbf{a}+\beta_{1} X_{1}+\beta_{2} X_{2}+\mathbf{e}
$$

\begin{tabular}{|c|c|c|c|c|c|}
\hline \multirow[t]{2}{*}{ Model } & \multicolumn{2}{|c|}{$\begin{array}{l}\text { Unstandardize } \\
\text { Coefficients }\end{array}$} & $\begin{array}{r}\text { Standardize } \\
\text { Coefficients }\end{array}$ & \multirow[t]{2}{*}{$t$} & \multirow[t]{2}{*}{ Sig } \\
\hline & B & $\begin{array}{l}\text { Std. } \\
\text { Error }\end{array}$ & Beta & & \\
\hline (Constant) & 1,55 & ,80 & & 1,93 &, 00 \\
\hline HARGA & 30 & 05 & ,26) & 5,67 &, 00 \\
\hline KUALITASPRODU| & ,87 & 03 & 1,18 & 25,51 &, 00 \\
\hline$Y=1,5$ & $54+$ & $305 x$ & $x 1+0,876$ & $5 \times 2$ & \\
\hline Keterang & & & & & \\
\hline $\mathrm{Y}=\mathrm{Mina}$ & $\mathrm{t} \mathrm{Bel}$ & & & & \\
\hline $\mathrm{X} 1=\mathrm{Ha}$ & & & & & \\
\hline $\mathrm{X} 2=\mathrm{Kua}$ & litas & rodul & & & \\
\hline - Konsta & nta & ebesa & 1,554 & dapat & \\
\hline diartika & an ba & wa 1 & Minat Beli & li $(Y)$ & \\
\hline akan bc & ernila & sebe & sar 1,554 & pada & \\
\hline saat $\mathrm{H}$ & Iarga & (X1) & dan $\mathrm{Ku}$ & dalitas & \\
\hline $\begin{array}{l}\text { Produk } \\
\text { ada) }\end{array}$ & (X2 & ber & lai nol & (tidak & \\
\hline
\end{tabular}

- Koefisien regresi Harga (X1) sebesar 0.305 hal ini mengandung arti bahwa kenaikan satu satuan Harga (X1) akan menaikkan Minat Beli (Y) sebesar 0.305

- Koefisien regresi Kualitas Produk (X2) sebesar 0,876 menyatakan bahwa setiap kenaikan satu satuan Kualitas Produk (X2) akan meningkatkan Minat Beli sebesar 0,876

\section{Pengujian Hipotesis \\ Pengujian Hipotesis Secara Parsial menggunakan Uji t}

Untuk melihat besarnya pengaruh antara Harga dan Kualitas Produk terhadap Minat Beli secara parsial, digunakan uji $\mathrm{t}$ dengan menggunakan tabel 1. Koefisien Regresi.

\section{a. Pengujian pengaruh Harga terhadap minat beli}

Untuk melihat apakah ada pengaruh positif dan signifikan antara harga 
p-ISSN : 2301-7775

e-ISSN : 2579-8014

JURNAL NIAGAWAN Vol 6 No 2 Oktober 2017

dengan minat beli, dapat dilakukan dengan analisis sebagai berikut:

Penentuan hipotesis:

Ho : Tidak ada pengaruh positif dan signifikan antara harga dan minat beli

$\mathrm{Ha}$ : Ada pengaruh positif dan signifikan antara harga dan minat beli

Dari perhitungan SPSS

diperoleh nilai t hitung sebesar 5,672 dan besarnya t tabel dengan ketentuan taraf signifikansi 95\% dan alpha 5\% serta derajat kebebasan (dk) dengan ketentuan $\mathrm{dk}=\mathrm{n}-2$ atau 100-2=98.dari ketentuan tersebut diperoleh angka $\mathrm{t}$ tabel sebesar 1,984.

Kriteria uji hipotesis adalah sebagai berikut :

Jika t hitung $>\mathrm{t}$ tabel, maka Ho ditolak dan Ha diterima

Jika t hitung < t tabel, maka Ho diterima dan Ha ditolak

Didasarkan hasil perhitungan, diperoleh nilai t hitung sebesar 5,672 > t tabel sebesar 1,984, maka Ho ditolak dan Ha diterima. Artinya, ada pengaruh positif dan signifikan antara harga dan minat beli.

\section{b. Pengujian Pengaruh Kualitas Produk terhadap Minat Beli}

Untuk melihat apakah ada pengaruh positif dan signifikan antar kualitas produk dan minat beli, dapat dilakukan dengan analisis sebagai berikut:

Dari perhitungan SPSS diperoleh nilai $\mathrm{t}$ hitung sebesar 25,511 dan besarnya t tabel dengan ketentuan taraf signifikansi $95 \%$ dan alpha $5 \%$ serta derajat kebebasan (dk) dengan ketentuan $\mathrm{dk}=\mathrm{n}-2$ atau 100-2=98.dari ketentuan tersebut diperoleh angka $\mathrm{t}$ tabel sebesar 1,984.
Didasarkan hasil perhitungan, diperoleh nilai t hitung sebesar 25,511 > t tabel sebesar 1,984, maka Ho ditolak dan Ha diterima. Artinya, ada pengaruh positif dan signifikan antara kualitas produk dan minat beli.

\section{Pengujian Hipotesis Secara Simultan menggunakan Uji-F}

Uji hipotesis secara simultan diperlukan untuk mengetahui apakah model regresi sudah benar atau tidak. Uji hipotesis menggunakan angka $\mathrm{F}$, yang diperoleh dai tabel Anova berikut ini :

Tabel 2. Hasil Uji F ANOVA $^{a}$

\begin{tabular}{|l|r|r|r|c|r|}
\hline Model & $\begin{array}{r}\text { Sum of } \\
\text { Squares }\end{array}$ & df & $\begin{array}{r}\text { Mean } \\
\text { Square }\end{array}$ & F & Sig. \\
\hline Regressio & 1016,00 & & 508,00 & 768,62 &, 000 \\
1 Residual & 64,10 & 9 &, 66 & & \\
Total & 1080,11 & 9 & & & \\
\hline
\end{tabular}

a. Dependent Variable: MINATBELI

b. Predictors: (Constant), KUALITASPRODUK, HARGA

Pengujian hipotesis dilakukan dengan cara membandingkan besarnya angka $\mathrm{F}$ penelitian dengan $\mathrm{F}$ tabel, dengan kriteria sebagai berikut :

Jika $\mathrm{F}$ hitung > F tabel, maka Ho ditolak dan Ha diterima

Jika $\mathrm{F}$ hitung $<\mathrm{F}$ tabel, maka Ho diterima dan Ha ditolak

Berdasarkan tabel 2, angka F penelitian yang diperoleh dari hasil perhitungan adalah sebesar 768,628. Sedangkan angka $F$ tabel dihitung dengan ketentuan yaitu taraf signifikan $95 \%$ dan alpha 5\% serta derajat kebebasan (dk) dengan ketentuan n-2= 100-2 = 98. Dengan ketentuan tersebut diperoleh angka $\mathrm{F}$ tabel 3,09. 
Dengan demikian diperoleh nlai $\mathrm{F}$ hitung $=768,628>\mathrm{F}$ tabel $=3,09$. Karena $\mathrm{F}$ hitung $>\mathrm{F}$ tabel yang berarti bahwa Ho ditolak dan $\mathrm{Ha}$ diterima, sehingga dapat disimpulkan bahwa terdapat pengaruh yang signifikan secara simultan antara Harga dan Kualitas Produk terhadap Minat beli.

\section{Koefisien Determinasi ( R Square )} Tabel 3. Tabel Koefisien Deteminasi

\begin{tabular}{|l|l|l|l|l|}
\hline Mode & $R$ & $\begin{array}{l}R \\
\text { Square }\end{array}$ & $\begin{array}{l}\text { Adjusted R } \\
\text { Square }\end{array}$ & $\begin{array}{l}\text { Durbin- } \\
\text { Watson }\end{array}$ \\
\hline 1 &, $970^{\mathrm{a}}$ &, 941 &, 939 & 2,136 \\
\hline
\end{tabular}

Determinan digunakan untuk mengetahuiseberapa besar variabel independen mampu menjelaskan pengaruh variabel dependen. Dari tabel 3. dapat diketahui besarnya angka $R^{2}$ adalah 0,941, yang berarti variabel harga (X1) dan Kualitas Produk (X2), menjelaskan pengaruh terhadap variabel Minat Beli (Y) sebesar 94,1\% ( $\mathrm{R}^{2} \mathrm{X}$ $100 \% ; 0,952$ X $100 \%=94,1 \%)$ sedangkan sisanya $5,9 \% \quad\left(100-R^{2}\right)$ dijelaskan oleh variabel-variabel lain diluar model penelitian ini.

\section{Pembahasan Hasil Penelitian}

Data dalam penelitian ini diperoleh dengan cara menyebarkan kuesioner kepada pembeli sayuran organik di Pasar Sambas Medan. Penelitian ini bertujuan untuk melihat pengaruh harga dan kualitas produk terhadap minat beli sayuran organik di Pasar Sambas Medan. Analisis yang digunakan dalam penelitian ini adalah analisis regresi linier berganda.
Berdasarkan jawaban responden pada variabel harga yang dilakukan terhadap 100 orang pembeli sayuran organik di Pasar Sambas Medan diperoleh hasil analisias regresi linier berganda dengan hasil yang menyatakan bahwa variabel harga berpengaruh positif dan signifikan terhadap minat beli. Hal ini sesuai dengan pendapat Dewa (2009) dengan menggunakan data empiris menunjukkan bahwa harga terbukti memiliki pengaruh yang positif dan signifikan terhadap minat beli konsumen.

Selain itu berdasarkan jawaban responden pada variabel kualitas produk yang dilakukan terhadap responden diperoleh hasil analisis regresi berganda dengan hasil yang menyatakan bahwa variabel kualitas produk berpengaruh positif dan signifikan terhadap minat beli. Hal ini didukung juga oleh penelitian Hidayat (2013) yang menyatakan bahwa Kualitas produk berpengaruh positif dan signifikan terhadap Minat Beli Ulang. Penjelasan tersebut dapat diartikan bahwa jika kualitas Produk tersebut lebih ditingkatkan maka terdapat pengaruh signifikan terhadap Minat Beli Ulang..

Dapat disimpulkan bahwa berdasarkan penelitian yang telah dilakukan, bahwa harga berpengaruh pada minat beli, dan kualitas produk berpengaruh pada minat beli. Berdasarkan penelitian ini pula dapat diketahui bahwa harga dan kualitas produk secara bersamaan dapat mempengaruhi minat beli, khususnya minat beli sayuran organik di Pasar Sambas Medan. 
p-ISSN : 2301-7775

e-ISSN : 2579-8014

JURNAL NIAGAWAN Vol 6 No 2 Oktober 2017

\section{KESIMPULAN DAN SARAN}

Berdasarkan hasil analisis dan pembahasan yang telah dilakukan dalam penelitian ini, maka terdapat beberapa kesimpulan sebagai berikut :

1. Berdasarkan uji determinan yang telah dilakukan, maka dapat diketahui bahwa pengaruh harga dan kualitas poduk terhadap variabel minat beli adalah sebesar sebesar $94,1 \%$ sedangkan sisanya $5,9 \%$ dijelaskan oleh variabelvariabel lain diluar penelitian yang dilakukan.

2. Setelah dilakukan uji hipotesis secara parsial ( Uji t) variabel harga dan kualitas produk secara parsial berpengaruh signifikan terhadap minat beli. Maka dapat disimpulkan bahwa hasil penelitian ini berhasil mendukung hipotesis pertama dan kedua yang dikemukakan pada penelitian.

3. Secara simultan variabel harga dan kualitas produk mempunyai pengaruh yang signifikan terhadap minat beli dan dari kedua variabel, harga (X1) dan Kualitas Produk (X2) yang mempunyai pengaruh yang paling dominan adalah Kualitas produk

4. Setelah dilakukan Uji hipotesis secara Simultan ( Uji F), variabel harga dan kualitas produk secara bersama-sama berpengaruh signifikan terhadap produktivitas kerja. Maka dapat disimpulkan bahwa hipotesis ketiga dari penelitian ini dapat didukung oleh hasil penelitian yang diperoleh.

\section{REFERENSI}

Ahmadi,Herman. 2013. Analisis Pengaruh Harga dan Kualitas Layanan Terhadap Minat Beli Ulang Gas Elpiji 3Kg dalam Meningkatkan Citra (Studi Kasus: Pada PT Hero gas jaya Ponorogo). Jurnal Ekomaks, 2(1):78-79

Andrianto, Hendra Noky. 2013. Pengaruh Kualitas Produk, Citra Merek, Harga dan Promosi Terhadap Keputusan Pembelian Mobil Jenis MPV Merek Toyota Kijang Innova di Semarang. Diponegoro Journal Of Management.2( 3) $\therefore$ : 10

Bungin, Burhan. 2011. Metodologi Penelitian Kuantitatif. Jakarta : Kencana.

Dewa, Ndaru Kusuma. 2009. Analisis Pengaruh Kualitas Produk, Daya Tarik Promosi dan Harga Terhadap Minat Beli (Studi Kasus StarOne di Area Jakarta Pusat). Thesis. Semarang:Universitas Diponegoro

Djarwanto dan Pangestu Subagyo. 2000. Statiktik Induktif. Edisi Keempat. Cetakan Kelima. BPFE. Yogyakarta.

Faradiba, Sri Rahayu Tri Astuti. 2013. Analisis Pengaruh Kualirtas Produk, Harga, Lokasi dan Kualitas Pelayanan Terhadap Minat Beli Ulang Konsumen (Studi pada Warung Makan "Bebek Gendut" Semarang. Diponegoro Journal Of Management, 3 (2):1-10 
Ferdinan A. 2002. Structural Equation Modelling Dalam Peneltian Manajemen.Edisi 2,Seri Pustaka Kunci 03/BPUNDIP

Fure,Hendra. $2013 . \quad$ Lokasi, Keberagaman Produk, Harga , dan Kualitas Pelayanan Pengaruhnya Terhadap Minat Beli Pada Pasar Tradisional Bersehati Calaca.Jurnal EMBA $1(3): 273-283$

Ghanimata, Fifyanita ,Mustafa Kamal. 2012. Analisis Pengaruh Harga, Kualitas Produk, dan Lokasi Terhadap Keputusan (Studi pada Pembeli Produk Bandeng Juwana Elrina Semarang). Diponegoro Journal of Management.1 (2) : 1-10

Ghozali,Imam. 2006. Aplikasi Analisis Multivariate Dengan Program SPSS.Semarang:

Badan Penerbit Universitas Diponegoro.

Hidayat, Arwan. 2013. Analisis Pengaruh Kualiatas Produk, Promosi dan Persepsi Harga Terhadap MInat Beli Ulang Pelanggan Voucher IsiUlang Xl di Universitas Semarang. Dinamika Manajemen.2(6):113-128

Kotler, Philip. 2009. Manajemen Pemasaran. Jakarta: Erlangga.

2005. Manajamen Pemasaran, Jilid 1 dan 2. Jakarta:PT. Indeks Kelompok Gramedia.

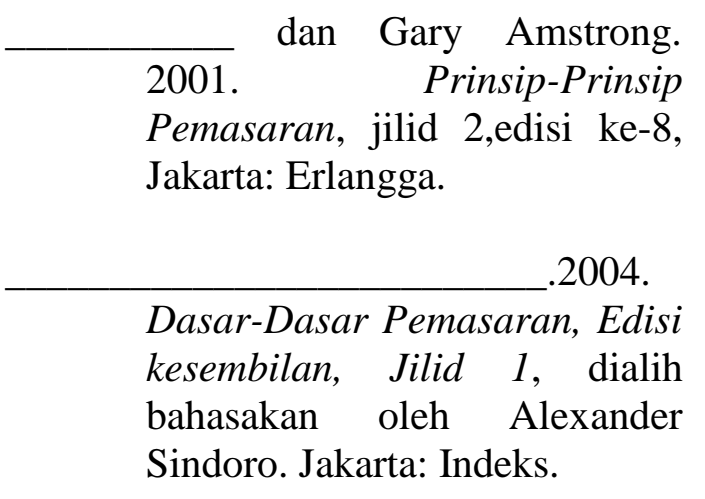
.2008

Prinsip-prinsip

Pemasaran,Jilid 1, Jakarta: Erlangga. dan Keller. 2012. Marketing Management.Edisi 14. Global Edition. Pearson Prentice Hall.

Kotler \& Kevin Lane Keller. 2009. Manajemen pemasaran,Edisi 13Jilid 1 Jakarta.

Lupiyoadi, Rambat.2001. Manajemen Pemasaran Jasa, Jakarta: Salemba Empat.

Pongoh, Melysa Elisabeth. 2013. Kualitas Pelayanan, Kualitas Produk, Dan Harga Pengaruhnya Terhadap Loyalitas Pelanggan Kartu As Telkomsel di Kota Manado. Jurnal EMBA 4(1): 86-94.

Saladin, Djaslim. 2003. Intisari Pemasaran dan Unsur-unsur Pemasaran, Cetakan Ketiga, Bandung:Linda Karya.

Pemasaran. Bandung:Lina Karya. 
p-ISSN : 2301-7775

e-ISSN : 2579-8014

JURNAL NIAGAWAN Vol 6 No 2 Oktober 2017

Schiffman \& Kanuk.2007. Perilaku Konsumen. Zulkifli Kasip (alih bahasa) Edisi Ketujuh. Penerbit PT. Indexs.

Simamora, Bilson. 2002. Panduan Riset Perilaku Konsumen. Jakarta: Gramedia PustakaUtama.

Sugiyono. 2007. Metode Penelitian Bisnis. Bandung: Alfabeta. .2008. Metode Penelitian Pendidikan :Pendekatan kuantitatif, dan $R \& D$. Bandung : Alfabeta. . 2009. Metode Penelitian Bisnis (Pendekatan Kuantitatif, Kualitatif, dan $R \& D)$. Bandung: Alfabeta. .2010. Metode Penelitian Kuantitatif Kualitatif \& RND. Bandung : Alfabet.

Sulistyari, Ikanita Novirina. 2012. Analisis Pengaruh Citra Merek, Kualitas Produk, dan Harga Terhadap Minat Beli Produk Oriflame. (Studi Kasus Mahasiswi Fakultas Ekonomika dan Bisnis Jurusan Manajemen Universitas Diponegoro Semarang (Studi Kasus Mahasiswi Fakultas Ekonomika dan Bisnis Jurusan Manajemen Universitas Diponegoro Semarang). Diponegoro Journal Of Management. 1( 1) : 1-17.

Sumarsono, 2004. Metode Penelitian Akuntansi Beserta Contoh Interprestasi Hasil Pengolahan Data. Edisi Revisi, Surabaya

Swastha, Basu. 2002. Azas-Azas Marketing.Yogyakarta:Liberty. dan Irawan. 2001. Manajemen Pemasaran Modern. Yogyakarta:Liberty.

Tandjung,J.W. 2004. Marketing Management:Pendekatan Pada Nilai-Nilai Pelanggan, Edisi Kedua,Cetakan Kedua, Malang: Bayu Media.

Thamrin. 2003. Riset Pemasaran,Edisi Tiga. Jakarta: Erlangga.

Tjiptono, Fandy. 2003.Strategi Pemasaran,Edisi Kedua,Yogyakarta : Penerbit Andi.

Jasa, Yogyakarta: Andi.

2004.Manajemen . 2005. Pemasaran

Jasa. Jawa Timur: Bayumedia Publishing. .2008. Strategi Bisnis Pemasaran. Yogyakarta: Andi. 